\title{
Spatially heterogeneous, synchronous settlement of Chthamalus spp. larvae in northern Baja California
}

\author{
Lydia B. Ladah ${ }^{1,4}$, Fabián J. Tapia ${ }^{3,5, *}$, Jesús Pineda ${ }^{3}$, Manuel López ${ }^{2}$ \\ ${ }^{1}$ Department of Biological Oceanography and ${ }^{2}$ Department of Physical Oceanography, CICESE, \\ Apartado Postal 2732, Ensenada, CP 22800 Baja California, Mexico \\ ${ }^{3}$ Biology Department, MS-34, Woods Hole Oceanographic Institution, Woods Hole, Massachusetts 02543, USA \\ ${ }^{4}$ Present address: PO Box 434844, San Diego, California 92143-4844, USA \\ ${ }^{5}$ Present address: Estación Costera de Investigaciones Marinas, Pontificia Universidad Católica de Chile Alameda 340, \\ Casilla 114-D, Santiago CP 6513677, Chile
}

\begin{abstract}
We evaluated the spatial variability in barnacle settlement at scales of $10 \mathrm{~s}$ to $100 \mathrm{~s}$ of meters (among-sites: $300 \mathrm{~m}$; within-site: $30 \mathrm{~m}$ ) along $1 \mathrm{~km}$ of coastline in the Bay of Todos Santos, northern Baja California, Mexico. Settlement of the intertidal barnacles Chthamalus spp. was monitored daily from April 1 to May 10, 2002, and thereafter every other day to September 18, 2002. Concurrently, temperature of the water column was measured every $15 \mathrm{~min}$, and hourly wind speed and direction data were acquired from a nearby site. We identified 12 settlement pulses during our study, with all but 2 pulses showing significant differences in mean settlement at either or both spatial scales. Despite a high variability in numbers, settlement pulses were synchronous between sites. The occurrence of settlement pulses was significantly correlated with a rapid increase in the stratification of nearshore waters, but not correlated with sudden fluctuations in the direction of winds perpendicular to the shore. Sudden changes in the stratification of nearshore waters have been associated with the occurrence of internal tidal bores. Our results suggest that internal motions, more specifically internal tidal bores, could be an important mechanism for the onshore transport of larvae in the Bay of Todos Santos.
\end{abstract}

KEY WORDS: Synchronous settlement $\cdot$ Spatial variability $\cdot$ Intertidal barnacle $\cdot$ Chthamalus $\cdot$ Baja California

Resale or republication not permitted without written consent of the publisher

\section{INTRODUCTION}

The distribution and abundance of marine populations is determined by a combination of pre- and postsettlement factors (Hatton 1938, Menge 1991, 2000, Roberts 1991). In particular, on rocky shores, where many benthic organisms have planktonic larval phases, larval settlement has been suggested to be a major factor regulating population structure (Underwood \& Denley 1984, Underwood \& Fairweather 1989, Caley et al. 1996, Miron et al. 1999, Menge 2000). Both settlement and recruitment in most benthic marine populations studied to date are highly variable at a number of temporal and spatial scales (Hawkins \& Hartnoll 1982, Caffey 1985, Connell 1985, Satumanat- pan et al. 1999, Jenkins et al. 2000, O'Riordan et al. 2004), and therefore difficult to characterize and predict (Hyder et al. 2001). Understanding this variability, however, is likely to provide insight into the processes that are most influential in determining the timing and intensity of settlement and recruitment.

The number of larvae available at any particular time and place is determined by the interactions of many biological and physical factors. Initially, the production of larvae depends on adult densities, as well as on the timing and intensity of adult reproduction (Pineda 2000). Upon entering the water column, the survival of larvae is mostly affected by predation (Rumrill 1990) and the availability of food (Morgan 1995). Once the larvae are competent to settle, the 
physical processes necessary for their onshore displacement (Shanks 1983, 1995, Farrel et al. 1991, Pineda 1991, 1999, 2000, Le Fèvre \& Bourget 1992, Shanks et al. 2000) interact with small-scale hydrodynamics (Eckman 1983), larval behavior (Le Fèvre \& Bourget 1992), the availability of suitable substrate (Raimondi 1988, Minchinton \& Scheibling 1993), and early post-settlement mortality (Gosselin \& Qian 1997, Hunt \& Scheibling 1997, Jarrett 2000) to result in highly variable spatial and temporal patterns in recruitment.

The physical mechanisms involved in the onshore transport of larvae span a wide range of temporal and spatial scales (seconds to months, and meters to kilometers). These mechanisms include wind-induced upwelling and relaxation (Farrel et al. 1991, Wing et al. 1995a,b, Shanks et al. 2000), surface winds and currents (Hawkins \& Hartnoll 1982, Bertness et al. 1996), linear internal waves (Norris 1963, Shanks 1983, 1986, 1987) and internal tidal bores (Pineda 1991, 1994a, 1999, Pineda \& López 2002). Once larvae have been transported onshore, settlement patterns may be determined by smaller-scale factors such as nearshore hydrodynamics, larval behavior, and substrate availability (Pineda 2000). It is not well understood how large-scale processes interact with smaller-scale modulating forces to determine the variability in larval supply, settlement rate, recruitment, and juvenile densi-

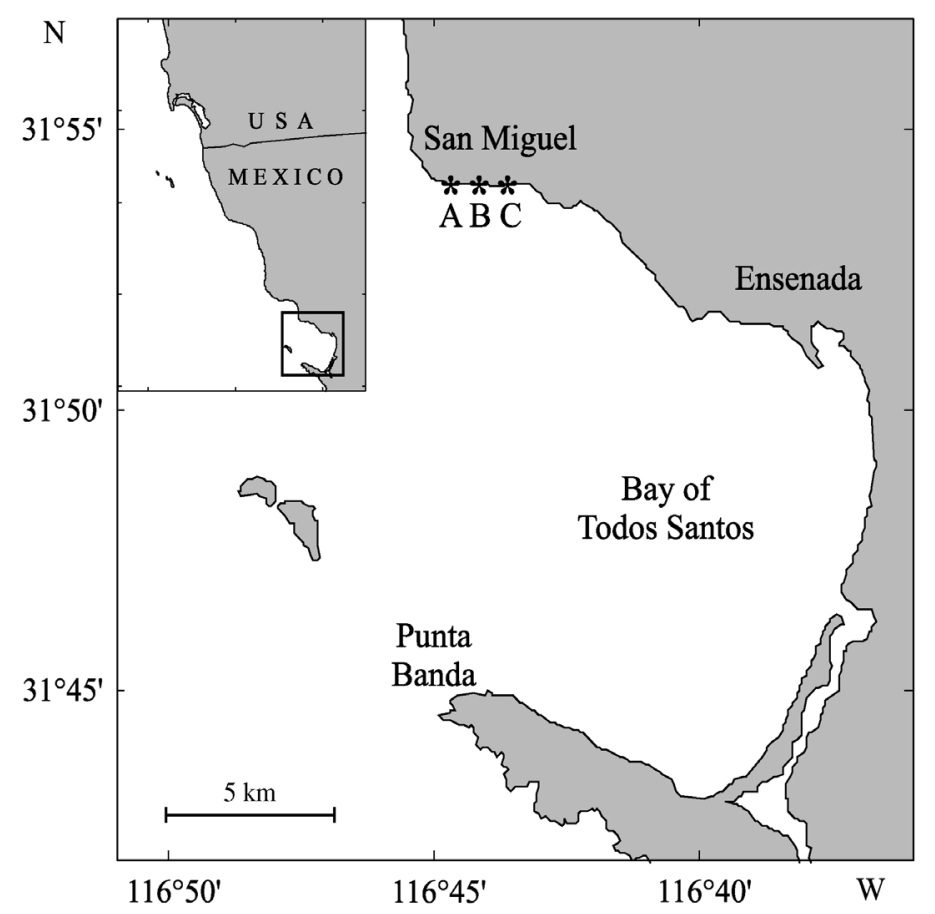

Fig. 1. Location of study site in northern Baja California, Mexico. Inset: position of Bay of Todos Santos in relation to USA-Mexico border ties at various spatial scales. Short- and long-term changes in such interactions, however, may affect the connectivity of populations at demographically and biogeographically relevant scales, with implications for limits of distribution and local extinctions (Gaylord \& Gaines 2000).

Many studies published to date have focused on the larger-scale variability of larval settlement and/or recruitment using long sampling intervals (Hawkins \& Hartnoll 1982, Hyder et al. 1998, Archambault \& Bourget 1999, Jenkins et al. 2000, Connolly et al. 2001), which have been correlated with physical mechanisms occurring at similar spatial and temporal scales. Studies conducted at smaller scales suggest that temporal variability in settlement rate might be related to larval pool and physical transport processes, while spatial variability might be associated with behavioral responses and substrate availability (Pineda 1994b). In this study we focused on smaller-scale spatial and temporal variability in settlement of the intertidal barnacle Chthamalus spp., which we observed over 1 recruitment season (April to September 2002) along a single shore in northern Baja California, Mexico. We explore the degree of synchrony across sites, and speculate on the underlying physical mechanisms that could explain the observed settlement patterns.

\section{MATERIALS AND METHODS}

Study site. Playa de San Miguel $\left(31^{\circ} 55^{\prime} \mathrm{N}, 116^{\circ} 38^{\prime} \mathrm{W}\right)$ is a wave-exposed, south-facing rocky shore, composed principally of weathered volcanic basalt boulders, located in the Bay of Todos Santos, northern Baja California, Mexico (Fig. 1). The beach is exposed to swell at angles of 185 to $300^{\circ}$ with respect to true north. The intertidal community includes leathery brown algae Egregia spp., seagrasses Phyllospadix spp., seastars Pisaster spp., purple sea urchins Strongylocentrotus purpuratus, mussels Mytilus spp., and the barnacles Chthamalus spp., Balanus glandula, Pollicipes polymerus and Tetraclita spp. Local oceanographic conditions are dominated by wind-induced upwelling in spring, solar heating of surface waters in summer, an energetic internal tide in the spring and summer (Tapia et al. 2004), and by wave activity in fall and winter.

Environmental data. Subtidal temperatures were measured between March and August 2002 with a string of temperature loggers (Onset Stow Away TidBits, Onset Computer) deployed about $1 \mathrm{~km}$ offshore of the site in $16 \mathrm{~m}$ depth. Loggers were placed at $1,4,7,10,13$ and $16 \mathrm{~m}$ above the bottom (mab) and programmed to record point measurements every $15 \mathrm{~min}$. 
Spectral analysis of the temperature series of $\sim 15000$ observations collected at each depth was performed to characterize temperature variability at the study site. The series of raw temperature data were linearly detrended and subdivided into non-overlapping segments of $2^{10}(10.6 \mathrm{~d})$ prior to the computation of an average Welch periodogram. In order to characterize the variability in stratification of the water column, we computed the square of the Brunt-Väisälä frequency $\left(N^{2}\right)$ for each one of the 5 pairs of temperature series (i.e. 1 to $4 \mathrm{mab}, 4$ to $7 \mathrm{mab}, 7$ to $10 \mathrm{mab}, 10$ to $13 \mathrm{mab}$ and 13 to $16 \mathrm{mab})$, as

$$
N^{2}=\frac{g}{\rho_{0}} \frac{\partial \rho}{\partial z}
$$

where $g$ is gravity $\left(9.8 \mathrm{~m} \mathrm{~s}^{-2}\right), \rho_{0}$ is the mean density of the water column, and $z$ is depth. The temperature time series were low-pass-filtered prior to the compu-

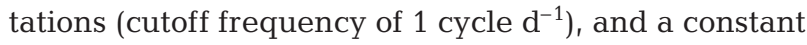
salinity value of 34 was assumed. A depth-averaged series of $N^{2}$, which we used in the analysis of temporal correlations between settlement and stratification (see next subsection), was obtained by vertically averaging the 5 temperature series.

Hourly wind data were gathered from a weather station at Punta Banda, on the southern tip of the Bay of Todos Santos, approximately $18 \mathrm{~km}$ south of our study site (Fig. 1). The orientation of the shoreline at the study site was $90^{\circ}$ with respect to true north. Thus, $\mathrm{N}-\mathrm{S}$ corresponded to cross-shore winds, whereas $\mathrm{E}-\mathrm{W}$ was alongshore.

Collector design, deployment, and recovery. To determine whether differences in the numbers of settling larvae occurred across spatial scales, 27 locations were chosen in a stratified, hierarchical manner. The shore was divided into 3 sites, each separated by about $300 \mathrm{~m}$ of coastline. Site A was located within the bay and protected from wave action. Site B was located on a semi-exposed point along the bay. Site $\mathrm{C}$ was located on a point exposed to wave action. Within each site (about $100 \mathrm{~m}$ long), 3 areas were chosen (nested within sites), each separated by $30 \mathrm{~m}$. Within each area, 3 collectors were deployed approximately $1 \mathrm{~m}$ apart. Settlement collectors were made of $11 \mathrm{~cm}$-long pieces of white PVC pipe ( $2.54 \mathrm{~cm}$ diam.), which were cut in half lengthwise and grooved in 3 areas. Settlement was only counted for larvae settling within ca. $0.0165 \mathrm{~cm}$ of the groove axis, which brought the area of available substrate to $1.9 \mathrm{~cm}^{2}$ per collector (Pineda 1994b). A hole was drilled in the center, so that the collectors could be attached to the substrate using stainless steel screws, which were cemented into holes drilled in the rock within the Chthamalus spp. zone.

Collectors were cured in seawater for 2 wk prior to the first deployment on April 1, 2002, and replaced daily by fresh collectors during the daytime low tide until May 15, 2002, after which time they were collected every other day until September 18, 2002. Recovered collectors were placed in individual plastic bags to prevent loss of settlers, and were returned to the laboratory where barnacles were identified and enumerated under a dissecting microscope. Adverse weather conditions precluded recovery of collectors on 10 April, and occasionally damaged or caused the loss of some collectors, which were immediately replaced.

Enumeration of settlers and data treatment. On each collection day, barnacles on collectors were identified to the genus level and the total number of larvae per collector was recorded. Although cyprid larvae (i.e. settled, unmetamorphosed) and spat (i.e. settled and recently metamorphosed individuals) were counted separately, here we report the total number of settlers (i.e. cyprids plus spat) counted per collector. Deployment time was used to standardize the number of settlers found during each collection to number of settlers $\mathrm{d}^{-1}$, as well as to convert the sampling frequency during the first month of our study from every day to every other day. Such standardization does not account for potential biases due to mortality during the $48 \mathrm{~h}$ deployments, but it was preferred over discarding data that were collected more frequently.

Settlement pulses were defined in the standardized settlement series as those days on which at least 1 site had an average daily settlement greater than an a priori selected threshold. The threshold was calculated by taking the average of the daily means across the entire study period for all collectors plus $3 \mathrm{SD}$.

Consistent with what is known about their settlement season in the region (e.g. Hines 1979, Pineda 1994b, Pineda \& López 2002), Chthamalus spp. dominated the settlement counts during our study. Unfortunately, we could not identify these settlers to the species level, as this remains difficult from a morphological point of view (see Miller et al. 1989). C. fissus is the species most likely to occur in the area; the second most probable species C. dalli has its southern limit around Point Conception, Central California, but can occur as far south as San Diego (W. Newman, pers. comm.). The northern limit of C. panamensis, another species of Chthamalus that could be present in the region, is located much further south, at $12^{\circ} \mathrm{N}$ on the Pacific coast of Mexico (see Table 1 in Wares 2001). Although most of the settlement probably corresponded to $C$. fissus, we submit that identifying settlers to the species level was not crucial for the purposes of our study, as larvae were used as a biological indicator of transport. Settlement of another common barnacle, Balanus glandula, was also observed in June and July. We do not report these results, however, as the settlement series was too short to allow a sound statistical analysis. 
Statistical analysis. To determine the spatial scales at which settlement was variable, a nested ANOVA ( $\alpha=0.05$ ) was used for each settlement pulse. We tested whether the mean number of settlers per day differed among sites (spatial scale of $300 \mathrm{~m}$; df =2), and among areas nested within sites (spatial scale of $30 \mathrm{~m}$; $\mathrm{df}=6$ ). Variances were tested for homogeneity using Cochran's C-test, and were log-transformed when necessary (Underwood 1997).

We assessed the degree of among-site synchrony in settlement by performing a Spearman rank-correlation analysis on the time series of average settlement per day of deployment. To prevent spurious correlations, the series were differenced prior to the analysis by subtracting settlement numbers between consecutive days (Pineda \& López 2002).

We used a randomization procedure similar to the 'Superposed Epoch Analysis' described by Prager \& Hoenig (1989) to test the statistical significance of a temporal correlation between settlement pulses and fluctuations in (1) the stratification of nearshore waters
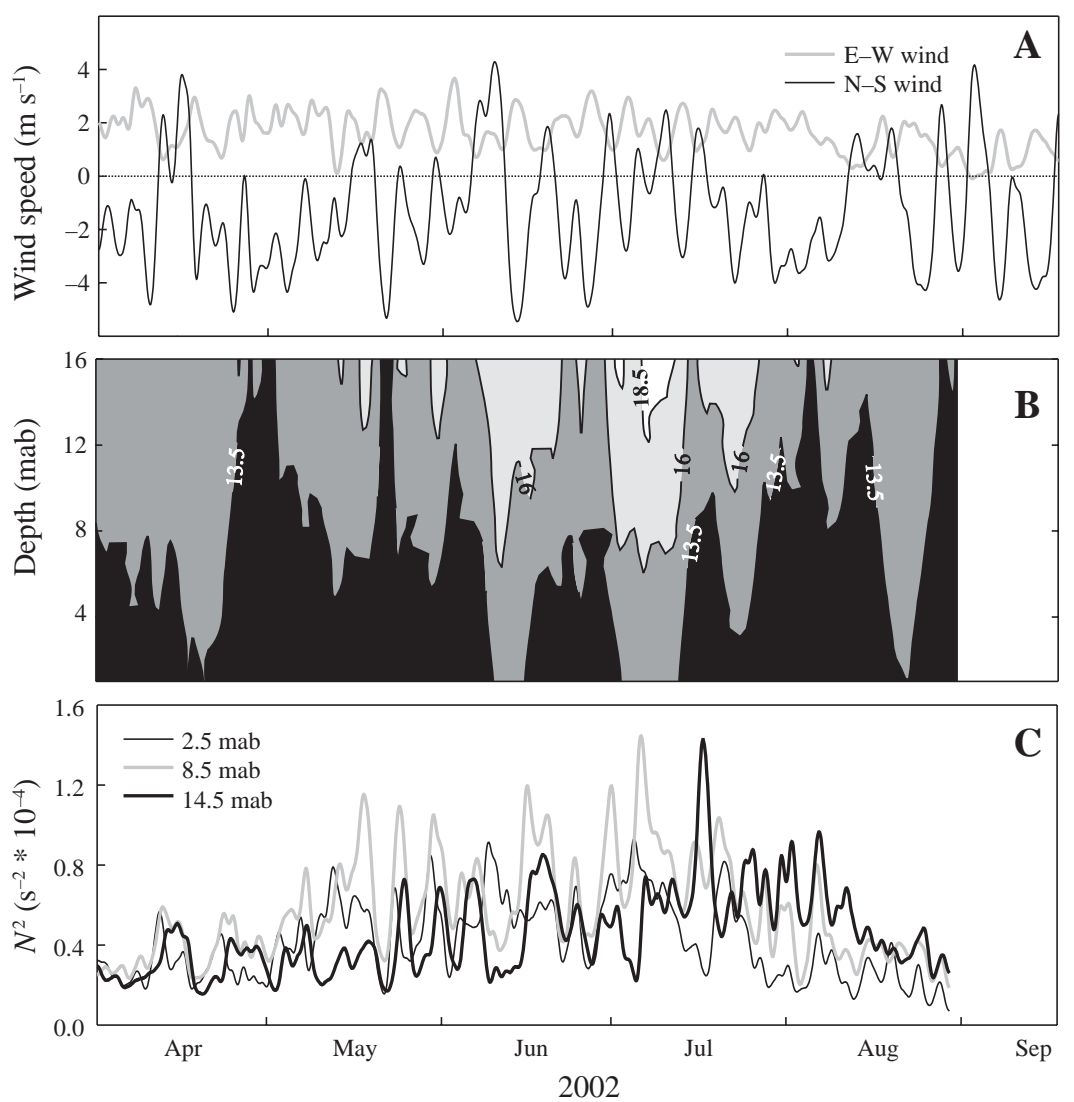

Fig. 2. Low-pass-filtered time series (cutoff frequency of 1 cycle per day, cpd) of environmental variables. (A) Winds recorded at Punta Banda, Bay of Todos Santos (N-S is perpendicular to shore at San Miguel, positive values correspond to onshore winds); (B) temperatures $\left({ }^{\circ} \mathrm{C}\right)$ recorded at 6 different depths in San Miguel; $(\mathrm{C})$ series of squared Brunt-Väisälä frequencies $\left(N^{2}\right)$ computed for pairs of temperature series (only 3 out of 5 computed series are shown) and (2) the direction of N-S winds, which were perpendicular to shore at the study site. Prior to the analysis, daily means were obtained from the depthaveraged series of stratification and from the hourly $\mathrm{N}-\mathrm{S}$ winds. As our interest was focused on fluctuations in the environmental variables (i.e. stratification and wind) around days when settlement pulses occurred, we used the test statistic:

$$
D=\sum_{i=1}^{N}\left(A_{i}-P_{i}\right)
$$

which is the sum of differences between measurements of the environmental variable after $(A)$ and prior $(P)$ to $N$ settlement pulses. $A$ and $P$ were defined as

$$
A_{i}=\left(E_{j}+E_{j+1}\right) / 2 \quad P_{i}=\left(E_{j-1}+E_{j-2}\right) / 2
$$

where $j$ is the day along the time series when a settlement pulse $i$ occurred, and $E$ corresponds to the environmental variable. Thus, the value of $D$ should be high if rapid increases in stratification or northward wind forcing co-occur with settlement pulses.

Under the null hypothesis, the occurrence of settlement pulses is independent of the value of the environmental variable (i.e. their occurrence along the time series is only determined by chance). In other words, if the null hypothesis is true, the value of $D$ computed for the original positions of settlement pulses $\left(D_{\text {obs }}\right)$ will not significantly differ from the values computed when the $N$ settlement pulses are allocated at random along the time series ( $\left.D_{\text {rand }}\right)$. If, on the other hand, the value of $D_{\text {obs }}$ is above the $(1-\alpha)$ th percentile of the $D_{\text {rand }}$ distribution, the null hypothesis is rejected.

The results of 5000 iterations of a randomization algorithm were used to obtain an empirical probability distribution for the test statistic $D$ under the null hypothesis. The $\mathrm{p}$-value for $D$ was estimated as $(x+1) /(I+1)$ (Edgington 1986), where $x$ is the number of $D_{\text {rand }}$ values that were greater than $D_{\text {obs, }}$ and $I$ is the number of iterations.

\section{RESULTS}

Hourly data collected at Punta Banda indicated that N-S winds had higher speeds and larger variability than E-W winds during the study period, with frequent and abrupt shifts 


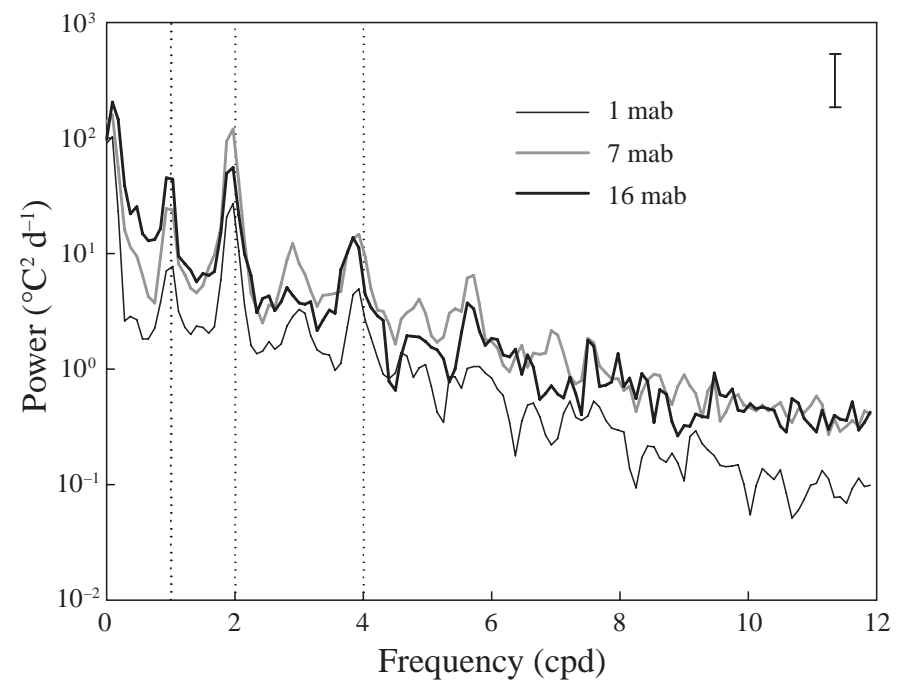

Fig. 3. Power spectra computed for temperature series collected at San Miguel between April and August 2002. For clarity, spectra computed for only 3 out of 6 depths are shown. Depth is in meters above bottom (mab). Prior to analysis, data were detrended using a $14 \mathrm{~d}$ running mean. Vertical bar corresponds to $95 \%$ confidence interval in wind direction from N-E to S-E (Fig. 2A). Semidiurnal intrusions of cold water near the bottom were common throughout the study period and appeared to be tidally generated (Figs. 2B \& 3). The temporal variability observed in the squared Brunt-Väisälä frequencies indicated a shoaling of the thermocline toward the end of our study (Fig. 2C). While mid-depth waters were most stratified in May to July, stratification was stronger near the surface in July to August (Fig. 2C).

Series of standardized settlement rates were obtained for a $170 \mathrm{~d}$ period at the 3 sites (Fig. 4C). Sites A and $\mathrm{C}$ generally had the highest number of settlers per unit time of deployment. Settlement pulses occurred in April to June and in September and were most concentrated in June; no pulses occurred in July or August (Fig. 4C). Pulses appeared to occur on days when rapid changes in onshore winds and nearshore stratification were recorded (Fig. 4A,B, respectively). There were episodes in the 24 or $48 \mathrm{~h}$ prior to each pulse when the difference between surface and bottom temperatures changed from highly stratified $\left(4\right.$ to $7^{\circ} \mathrm{C}$ difference between surface and bottom) to fairly homogeneous ( 0 to $2{ }^{\circ} \mathrm{C}$ difference between surface and bottom), and then switched back again to highly stratified in a matter of 1 to $2 \mathrm{~h}$. Peaks in settlement were synchronous at all sites (Fig. 4C), and significant correlations were found between the series of average settlement at the 3 sites (Table 1). We identified 12 settlement pulses, 10 of which showed a significant difference in mean settlement among sites or within sites (Table 2); 4 settlement pulses showed significant differences at the among-site scale only (i.e. $300 \mathrm{~m}$ ); 4 pulses showed significant differences at the withinsite scale only (i.e. $30 \mathrm{~m}$ ); and

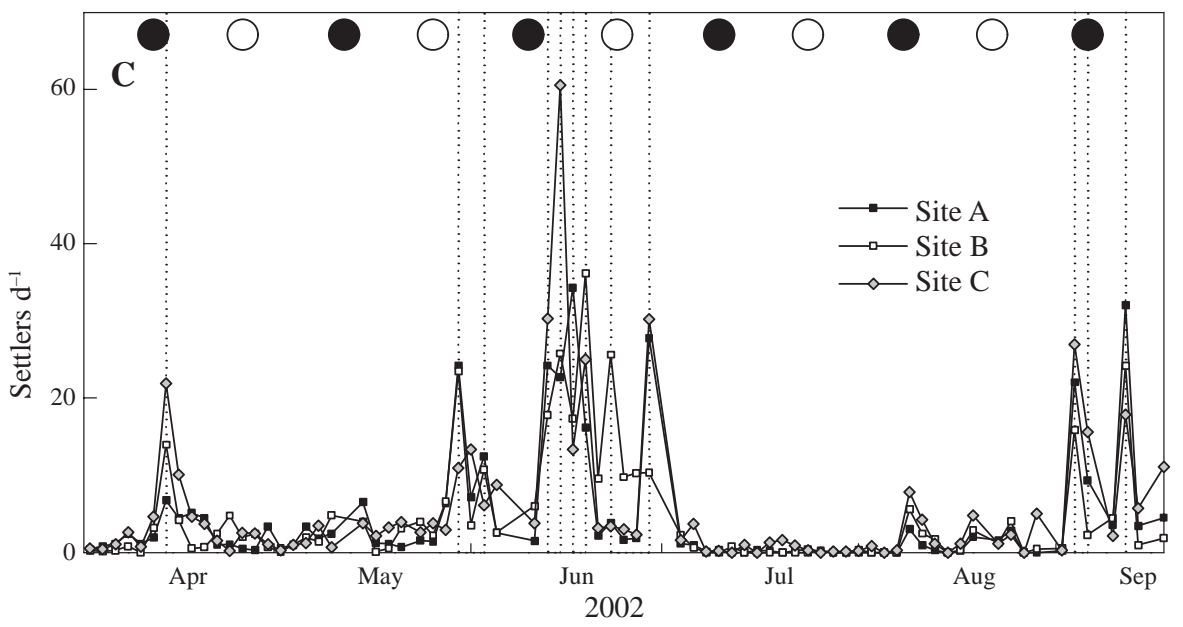

Fig. 4. Environmental variables and Chthamalus spp. settlement. (A) Series of daily means computed for $\mathrm{N}-\mathrm{S}$ winds (positive values correspond to onshore winds); (B) detrended series of daily stratification values, computed from depth-averaged series of Brunt-Väisälä frequency; (C) settlement time series recorded for intertidal barnacle Chthamalus spp. at San Miguel in April to September 2002. (O), (O) periods of new and full moon, respectively; vertical dotted lines indicate settlement pulses 
Table 1. Chthamalus spp. Correlation between series of average settlement. Spearman's rank-correlation coefficients in boldface; asterisks indicate significance levels. ${ }^{*} \mathrm{p}<0.01$; ${ }^{* *} \mathrm{p}<0.001$

\begin{tabular}{|lccc|}
\hline Site & A & B & C \\
\hline A & - & ${ }^{* *}$ & ${ }^{*}$ \\
B & $\mathbf{0 . 4 8 8}$ & - & ${ }^{* *}$ \\
C & $\mathbf{0 . 3 5 3}$ & $\mathbf{0 . 4 4 5}$ & - \\
\hline
\end{tabular}

finally, 2 settlement pulses showed a significant difference at both spatial scales (Table 2).

Of 12 settlement pulses, 7 occurred during periods surrounding the first and third quarters of the lunar cycle, while only 1 settlement pulse occurred on days with full or new moons (Fig. 4C). Timing of settlement pulses was significantly correlated with rapid changes in water column stratification ( $\mathrm{p}=0.013$, Fig. 5A). Although the fluctuations in wind forcing and stratification were cross-correlated (Spearman's rank correlation: $\mathrm{R}_{\mathrm{S}}=0.436, \mathrm{p}<0.01$ ), the timing of settlement pulses was not significantly correlated with sudden increases in onshore wind-forcing (Fig. 5B).

\section{DISCUSSION}

Our results indicate a significant correlation between the occurrence of settlement pulses of Chthamalus spp. and the increase in stratification of the water column, with synchronous, although spatially heterogeneous, settlement at all 3 sites at the scales considered in this study (30 and $300 \mathrm{~m}$ ). It is difficult to clearly identify the mechanism or mechanisms respon-
Table 2. Chthamalus spp. Results of ANOVA computed for each settlement pulse

\begin{tabular}{|lcccc|}
\hline $\begin{array}{l}\text { Date } \\
\text { (2002) }\end{array}$ & \multicolumn{2}{c}{$\begin{array}{c}\text { Site } \\
(\mathrm{df}=2)\end{array}$} & \multicolumn{2}{c|}{$\begin{array}{c}\text { Area (within site) } \\
(\mathrm{df}=6)\end{array}$} \\
& $F$ & $\mathrm{p}$ & $F$ & $\mathrm{p}$ \\
\hline 14 Apr & 3.96 & $\mathbf{0 . 0 4}$ & 5.04 & $\mathbf{0 . 0 0 5}$ \\
30 May & 2.59 & 0.10 & 3.43 & $\mathbf{0 . 0 2}$ \\
03 Jun & 0.33 & 0.72 & 4.09 & $\mathbf{0 . 0 0 9}$ \\
13 Jun & 2.27 & 0.13 & 0.52 & 0.785 \\
15 Jun & 11.15 & $<\mathbf{0 . 0 0 1}$ & 0.9 & 0.50 \\
17 Jun & 3.77 & $\mathbf{0 . 0 4}$ & 1.09 & 0.41 \\
19 Jun & 0.56 & 0.58 & 1.51 & 0.23 \\
23 Jun & 12.46 & $<\mathbf{0 . 0 0 1}$ & 3.8 & $\mathbf{0 . 0 1 5}$ \\
29 Jun & 4.75 & $\mathbf{0 . 0 2}$ & 0.49 & 0.80 \\
04 Sep & 0.98 & 0.39 & 6.76 & $\mathbf{0 . 0 0 1}$ \\
06 Sep & 4.9 & $\mathbf{0 . 0 2}$ & 1.88 & 0.15 \\
12 Sep & 1.26 & 0.31 & 3.35 & $\mathbf{0 . 0 2 9}$ \\
\hline
\end{tabular}

sible for these patterns without a more extensive survey of physical conditions and larval distribution in the study area. Our results, however, lead us to suggest that internal tidal motions modulate the timing of Chthamalus spp. larval arrival and are probably responsible for the temporally correlated settlement of other barnacle species at San Miguel (Balanus glandula, results not shown).

The spectral densities computed from our temperature data indicate that thermal variability in the water column was dominated by tidally-forced internal motions and, to a lesser extent, by solar heating. Semidiurnal frequencies dominated the variability of temperature near the bottom (Fig. 3, 1 mab), whereas both tidal forces and solar heating appeared important at the surface (Fig. 3, 16 mab). The secondary peaks ob-
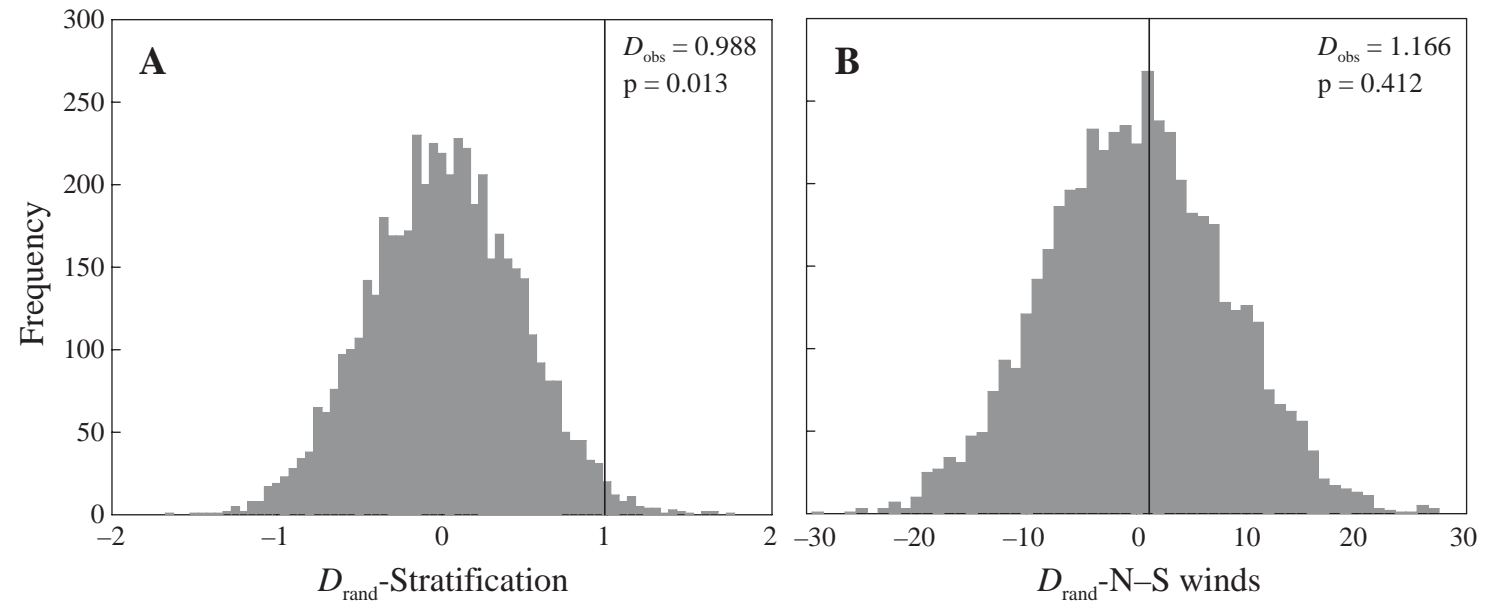

Fig. 5. Results of randomization test to determine significance of temporal correlations between Chthamalus spp. settlement pulses and (A) fluctuations in stratification of nearshore waters, and (B) velocity of winds perpendicular to shore at the study site. Empirical probability distributions for the test statistic $D$ (shading) were obtained from 5000 iterations of an algorithm that randomly allocated 9 and 12 settlement pulses along 151 and $170 \mathrm{~d}$ time series for stratification and winds, respectively. Vertical lines indicate position of $D_{\text {obs }}$ (i.e. value of $D$ computed from observed positions of settlement pulses) on each distribution 
served at frequencies of 3 and 4 cycles $\mathrm{d}^{-1}$ are indicative of non-linear effects characteristic of nearshore internal tides, and could be related to an interaction between ebb/flood currents and the local topography. A dominance of tidal forces along with the high stratification observed in the water column prior to settlement pulses (Fig. 4) comprise suitable conditions for the occurrence of internal tidal bores in nearshore waters. We suggest that these were responsible for the onshore transport of larvae during this study. The correlation between settlement of barnacle larvae and temperature drops characteristic of internal tidal bores has been documented by other studies in the NE Pacific (Pineda 1991). The temporal correlation between settlement pulses and the occurrence of fluctuations in stratification, often indicative of the shoaling of the internal tide and the occurrence of internal tidal bores (Pineda \& López 2002), would provide further support for our interpretation.

The randomization analysis indicated a significant correlation between the timing of settlement pulses and sudden changes in stratification (Fig. 5A). The correlation was significant despite the fact that on several occasions we observed fluctuations in the stratification of the water column but no settlement pulses (for example, see August in Fig. 4). This is probably because larvae are not always present in the water, even if the physical mechanisms that bring them onshore are acting. Our analysis of temporal correlations between biological and physical time series is based on the approach presented more than a decade ago by Prager \& Hoenig (1989, 1992), who used a similar algorithm to test the significance of correlations between time series for chub mackerel Scomber japonicus recruitment off the coast of Southern California and changes in sea level associated with El Niño events. We consider this a valid and straightforward approach to the analysis of correlations between settlement and environmental time series.

Settlement pulses were synchronous at the 3 sites and predominantly occurred in spring and summer, when internal tidal bores are prevalent in Southern and Baja California (Pineda 1991, 1995). Water column temperatures were most stratified during the summer months, providing the necessary conditions for the occurrence of internal tidal bores. Internal tidal bores tend to occur on Days 7 to 12 and 19 to 24 of the lunar cycle (i.e. first and third quarters of the moon), where Day 1 is the day after the new moon. Apparently, few bores occur around new or full moon (Pineda 1995), consistent with the timing of the settlement pulses in this study. Internal tidal waves and bores are not always correlated with the lunar cycle and can be modulated by other coastal processes as well (Pineda \& López 2002). Thus, a strict lunar periodicity in settle- ment, which we did not observe in our results, would not necessarily provide evidence for larval transport by internal tidal bores. Settlement, however, was statistically correlated with nearshore stratification - a condition necessary for internal tidal bores - and was synchronous across the sites, suggesting common larval transport events for all sites.

The spatial heterogeneity in larval settlement detected in this study at the scale of 10 s to 100 s of meters has been reported in other studies of invertebrate larval settlement at similar spatial scales (Judge et al. 1988, Carroll 1996, Archambault \& Bourget 1999, Jenkins et al. 2000). However, due to a low sampling frequency in many of these studies (weekly to monthly), most of the results refer to differences in recruitment patterns (i.e. survivorship after settlement), rather than spatial differences in settlement (but see Pineda 1994b for a study with daily measurements). Studies of larval settlement and recruitment at larger scales (100s of meters to kilometers) have yielded mixed results (Ebert et al. 1994, Jenkins et al. 2000, Connolly et al. 2001, O'Riordan et al. 2004). Spatial coherence in settlement over larger scales has been interpreted in terms of mesoscale patterns of retention/advection associated with coastal upwelling (Ebert et al. 1994), or spatially-consistent onshore winds across a large area (Bertness et al. 1996, Jeffery \& Underwood 2000). Spatial heterogeneity in settlement numbers, on the other hand, has been interpreted as a result of the interaction between small-scale variability of transport mechanisms and larval behavior. Behavior and the local availability of suitable substrate might explain differing settlement numbers at the within-site scale in this study (see Raimondi \& Keough 1990, Pineda 1994b, Hyder et al. 1998). Among-site differences could be explained in terms of varying wave action (Caffey 1985) and onshore winds at a scale of $10 \mathrm{~s}$ of kilometers (Hawkins \& Hartnoll 1982), differing shoreline configuration at scales of 100s of meters (Archambault \& Bourget 1999), varying mesoscale physical processes over scales of 100 s to 1000s of kilometers (Connolly et al. 2001), and differences in water column stratification (Pineda \& López 2002).

The specific mechanism responsible for the spatial heterogeneity in the number of larval settlers detected in this study is difficult to discern. Given the spatial and temporal scale of the observations, our results may reflect spatial heterogeneity of larval distribution in the plankton, a spatial difference in their onshore transport, or differences in suitable substrate area for settlement. If the offshore larval pool was uniform at the spatial scales of this shore, as has been suggested for fish larvae and zooplankton patches across scales of 1 to $2 \mathrm{~km}$ (Jahn \& Lavenberg 1986), and the transport processes varied at this spatial scale, or there were 
differences in suitable substrate area around the collectors (which may have affected settlement on the collectors), then heterogeneous spatial settlement would be expected. Suitable substrate does not seem to be limiting at San Miguel (L. B. Ladah pers. obs.). Unfortunately, we cannot reach any conclusions as to the degree of patchiness of the offshore larval pool without extensively surveying the local meroplankton and suitable substrate area.

While it is difficult to identify and tease apart the exact mechanism by which spatial patterns in settlement arise at scales of meters to 100 s of meters, our results allow us to speculate on 1 specific mechanism that could explain the observed patterns. The temporal pattern of settlement suggests that onshore larval transport at San Miguel is mediated by internal tidal bores. The spatial variability, however, could have been the result of any combination of the 3 mechanisms described above (i.e. heterogeneous nearshore larval abundance, heterogeneous larval delivery, or/and variability in suitable substrate area).

Acknowledgements. Research was supported in part by AMELIS Project J37689/V from CONACYT and UC MEXUS grants to L.B.L., F.T. and J.P., and the wind measurements were partially supported by the US National Science Foundation. Fernando Miranda provided technical assistance with the collection of wind data. We thank J. Leichter and V. Starczak for their comments on an earlier version of the manuscript. This is a contribution to the scientific agennda of EPCOR-IAI (Eastern Pacific Consortium of the InterAmerican Institute for Global Change Research) CRN-062.

\section{LITERATURE CITED}

Archambault P, Bourget E (1999) Influence of shoreline configuration on spatial variation of meroplanktonic larvae, recruitment and diversity of benthic subtidal communities. J Exp Mar Biol Ecol 241:309-333

Bertness MD, Gaines SD, Wahle RA (1996) Wind-driven settlement patterns in the acorn barnacle Semibalanus balanoides. Mar Ecol Prog Ser 137:103-110

Caffey HM (1985) Spatial and temporal variation in settlement and recruitment of intertidal barnacles. Ecol Monogr 55:313-332

Caley MJ, Carr MH, Hixon MA, Hughes TP, Jones GP, Menge BA (1996) Recruitment and the local dynamics of open marine populations. Annu Rev Ecol Syst 27:477-500

Carroll ML (1996) Barnacle population dynamics and recruitment regulation in south central Alaska. J Exp Mar Biol Ecol 199:285-302

Connell JH (1985) The consequences of variation in initial settlement vs. post-settlement mortality in rocky intertidal communities. J Exp Mar Biol Ecol 93:11-45

Connolly SR, Menge BA, Roughgarden J (2001) A latitudinal gradient in recruitment of intertidal invertebrates in the northeast Pacific Ocean. Ecology 82:1799-1813

Ebert TA, Schroeter SC, Dixon JD, Kalvass P (1994) Settlement patterns of red and purple sea urchins (Strongylocentrotus franciscanus and $S$. purpuratus) in California, USA. Mar Ecol Prog Ser 111:41-52
Eckman JE (1983) Hydrodynamic processes affecting benthic recruitment. Limnol Oceanogr 28:241-257

Edgington ES (1986) Randomization tests. In: Kotz S, Johnson $\mathrm{N}$ (eds) Encyclopedia of statistical sciences, Vol. 7. Wiley, New York, p 530-583

Farrel TM, Bracher D, Roughgarden J (1991) Cross-shelf transport causes recruitment to intertidal populations in central California. Limnol Oceanogr 36:279-288

Gaylord B, Gaines SD (2000) Temperature or transport? Range limits in marine species mediated solely by flow. Am Nat 155:769-789

Gosselin LA, Qian PY (1997) Juvenile mortality in benthic marine invertebrates. Mar Ecol Prog Ser 146:265-282

Hatton H (1938) Essais de bionomie explicative sur quelques espèces intercotidales d'algues et d'animaux. Ann Inst Océanogr 17:241-348

Hawkins SJ, Hartnoll RG (1982) Settlement patterns of Semibalanus balanoides (L.) in the Isle of Man (1977-1981). J Exp Mar Biol Ecol 62:271-283

Hines AH (1979) The comparative reproduction ecology of three species of intertidal barnacles. In: Stancyk SE (ed) Reproductive ecology of marine invertebrates. University of South Carolina Press, Columbia, p 213-234

Hunt HL, Scheibling RE (1997) Role of early post-settlement mortality in recruitment of benthic marine invertebrates. Mar Ecol Prog Ser 155:269-301

Hyder K, Johnson MP, Hawkins SJ, Gurney WSC (1998) Barnacle demography: evidence for an existing model and spatial scales of variation. Mar Ecol Prog Ser 174:89-99

Hyder K, Åberg P, Johnson MP, Hawkins SJ (2001) Models of open populations with space-limited recruitment: extension of theory and application to the barnacle Chthamalus montagui. J Anim Ecol 70:853-863

Jahn AE, Lavenberg RJ (1986) Fine-scale distribution of nearshore, suprabenthic fish larvae. Mar Ecol Prog Ser 31: $223-231$

Jarrett JN (2000) Temporal variation in early mortality of an intertidal barnacle. Mar Ecol Prog Ser 204:305-308

Jeffery CJ, Underwood AJ (2000) Consistent spatial patterns of arrival of larvae of the honeycomb barnacle Chamaesipho tasmanica Foster and Anderson in New South Wales. J Exp Mar Biol Ecol 252:109-127

Jenkins SR, Åberg P, Cervin G, Coleman RA and 9 others (2000) Spatial and temporal variation in settlement and recruitment of the intertidal barnacle Semibalanus balanoides (L.) (Crustacea: Cirripedia) over a European scale. J Exp Mar Biol Ecol 243:209-225

Judge ML, Quinn JF, Wolin CL (1988) Variability in recruitment of Balanus glandula (Darwin, 1854) along the central California coast. J Exp Mar Biol Ecol 119:235-251

Le Fèvre J, Bourget E (1992) Hydrodynamics and behaviour: transport processes in marine invertebrate larvae. Trends Ecol Evol 7:288-289

Menge BA (1991) Relative importance of recruitment and other causes of variation in rocky intertidal community structure. J Exp Mar Biol Ecol 146:69-100

Menge BA (2000) Recruitment vs. postrecruitment processes as determinants of barnacle population abundance. Ecol Monogr 70:265-288

Miller KM, Blower SM, Hedgecock D, Roughgarden J (1989) Comparison of larval and adult stages of Chthamalus dalli and Chthamalus fissus (Cirripedia: Thoracica). J Crustac Biol 9:242-256

Minchinton TE, Scheibling RE (1993) Free space availability and larval substratum selection as determinants of barnacle population structure in a developing rocky intertidal community. Mar Ecol Prog Ser 95:233-244 
Miron G, Boudreau B, Bourget E (1999) Intertidal barnacle distribution: a case study using multiple working hypotheses. Mar Ecol Prog Ser 189:205-219

Morgan SG (1995) Life and death in the plankton: larval mortality and adaptation. In: McEdward L (ed) Ecology of marine invertebrate larvae. CRC Press, Boca Raton, FL, p 279-321

Norris KS (1963) The function of temperature in the ecology of the percoid fish Girella nigricans (Ayres). Ecol Monogr 33: 23-62

O'Riordan RM, Arenas F, Arrontes J, Castro JJ and 13 others (2004) Spatial variation in the recruitment of the intertidal barnacles Chthamalus montagui Southward and Chthamalus stellatus (Poli) (Crustacea: Cirripedia) over an European scale. J Exp Mar Biol Ecol 304:243-264

Pineda J (1991) Predictable upwelling and the shoreward transport of planktonic larvae by internal tidal bores. Science 253:548-551

Pineda J (1994a) Internal tidal bores in the nearshore: warmwater fronts, seaward gravity currents and the onshore transport of neustonic larvae. J Mar Res 52:427-458

Pineda J (1994b) Spatial and temporal patterns in barnacle settlement rate along a southern California rocky shore. Mar Ecol Prog Ser 107:125-138

Pineda J (1995) An internal tidal bore regime at nearshore stations along western USA: predictable upwelling within the lunar cycle. Cont Shelf Res 15:1023-1041

Pineda J (1999) Circulation and larval distribution in internal tidal bore warm fronts. Limnol Oceanogr 44:1400-1414

Pineda J (2000) Linking larval settlement to larval transport: assumptions, potentials, and pitfalls. In: Färber-Lorda J (ed) Oceanography of the Eastern Pacific, Vol 1. CICESE, Ensenada, p 84-105

Pineda J, López M (2002) Temperature, stratification and barnacle larval settlement in two Californian sites. Cont Shelf Res 22:1183-1198

Prager MH, Hoenig JM (1989) Superposed epoch analysis: a randomization test of environmental effects on recruitment with application to chub mackerel. Trans Am Fish Soc 118:608-618

Prager MH, Hoenig JM (1992) Can we determine the significance of key-event effects on a recruitment time series? A power study of superposed epoch analysis. Trans Am Fish Soc 121:123-131

Raimondi PT (1988) Rock type affects settlement, recruitment, and zonation of the barnacle Chthamalus anisopoma Pilsbury. J Exp Mar Biol Ecol 123:253-267

Raimondi PT, Keough MJ (1990) Behavioural variability in marine larvae. Aust J Ecol 15:427-437

Roberts CM (1991) Larval mortality and the composition of coral reef fish communities. Trends Ecol Evol 6:83-87

Editorial responsibility: Otto Kinne (Editor-in-Chief), Oldendorf/Luhe, Germany
Rumrill SS (1990) Natural mortality of marine invertebrate larvae. Ophelia 32:163-198

Satumanatpan S, Keough MJ, Watson GF (1999) Role of settlement in determining the distribution and abundance of barnacles in a temperate mangrove forest. J Exp Mar Biol Ecol 241:45-66

Shanks AL (1983) Surface slicks associated with tidally forced internal waves may transport pelagic larvae of benthic invertebrates and fishes shoreward. Mar Ecol Prog Ser 13: $311-315$

Shanks AL (1986) Tidal periodicity in the daily settlement of intertidal barnacle larvae and a hypothesized mechanism for the cross-shelf transport of cyprids. Biol Bull (Woods Hole) 170:429-440

Shanks AL (1987) The onshore transport of an oil spill by internal waves. Science 235:1198-1200

Shanks AL (1995) Mechanisms of cross-shelf dispersal of larval invertebrates and fish. In: McEdward L (ed) Ecology of marine invertebrate larvae. CRC Press, Boca Raton, FL, p 323-367

Shanks AL, Largier JL, Brink L, Brubaker J, Hoof R (2000) Demonstration of the onshore transport of larval invertebrates by the shoreward movement of an upwelling front. Limnol Oceanogr 45:230-236

Tapia FJ, Pineda J, Ocampo-Torres FJ, Fuchs HL, Parnell PE, Montero P, Ramos S (2004) High-frequency observations of wind-forced onshore transport at a coastal site in Baja California. Cont Shelf Res 24:1573-1585

Underwood AJ (1997) Experiments in ecology: their logical design and interpretation using analysis of variance. Cambridge University Press, New York

Underwood AJ, Denley EJ (1984) Paradigms, explanations, and generalizations in models for the structure of intertidal communities on rocky shores. In: Strong DR, Simberloff D, Abele LG, Thistle AB (eds) Ecological communities: conceptual issues and the evidence. Princeton University Press, Princeton, NJ, p 151-180

Underwood AJ, Fairweather PG (1989) Supply-side ecology and benthic marine ecology. Trends Ecol Evol 4: $16-20$

Wares JP (2001) Patterns of speciation inferred from mitochondrial DNA in North American Chthamalus (Cirripedia: Blanomorpha: Chthamaloidea). Mol Phylogenet Evol 18:104-116

Wing SR, Botsford LW, Largier JL, Morgan LE (1995a) Spatial structure of relaxation events and crab settlement in the northern California upwelling system. Mar Ecol Prog Ser 128:199-211

Wing SE, Largier JL, Botsford LW, Quinn JF (1995b) Settlement and transport of benthic invertebrates in an intermittent upwelling region. Limnol Oceanogr 40:316-329

Submitted: September 9, 2004; Accepted: March 31, 2005

Proofs received from author(s): October 5, 2005 